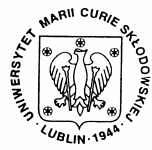

Annales UMCS Informatica AI 8(1) (2008) 203-212

$10.2478 / \mathrm{v} 10065-008-0019-\mathrm{Z}$

Annales UMCS

Informatica

Lublin-Polonia

Sectio AI

http://www.annales.umcs.lublin.pl/

\title{
Perspectives for using software agents in e-Government applications
}

\author{
Zbigniew Piotrowski* \\ Faculty of Computer Science and Information Systems, Szczecin University of Technology, \\ Żotnierska 49, 71-210 Szczecin, Poland
}

\begin{abstract}
Governing a country includes a set of decentralised processes. Moreover, in the unions of countries with integrated economic space, the decentralisation issue gains the attention. The most known examples of federated governments are two of the biggest world economies: the United States of America and the European Union. The decentralisation is even more significant when considering resources for businesses. Specifically the workforce, the land and the infrastructure are commonly managed at the local or the sub-local level. The paper addresses the issues concerning citizens' mobility (both for personal and professional purposes) and businesses' pan-European operations.

Application of autonomous software agents to aid cross-border businesses operations and citizens movements is addressed. The paper presents the possibility of making citizens' movements smoother and involving less paperwork. To support these ideas, the foundations and conclusions from Infocitizen initiative are introduced.

In the conclusions of the paper, it is suggested that the agent-based technology for opening agents-ready virtual offices by agencies at all levels of government should be used. It would benefit the users if they were allowed to set up software agents to act on their behalf and to search all possible locations in order to find required resources. The mentioned task would be impossible or extremely resource-consuming when done manually.
\end{abstract}

\section{Introduction}

The purpose of the Lisbon Strategy, drawn up by the European Union (EU), is to make European economy the world's most competitive economy in terms of innovation, social inclusion, liberalisation and enterprise environment. The competitiveness of the EU is still behind the world's most developed economies which are the USA and a group of "Asian tigers": Japan, Hong Kong, the Republic of Korea, Singapore and Taiwan. In 2006 the EU average indicators were still far behind the leaders in the vast majority of analysed categories. To face that challenge, in February 2005 the Lisbon Strategy was re-launched with

*e-mail address: zpiotrowski@wi.ps.pl 
new guidelines. The "Working together for growth and jobs" [1] strategy directs the main effort of the EU to make Europe a more attractive place to invest and work. To achieve that goal the EU needs to improve regulations and create a consistent single market without any obstacles. Switching to Euro - the common currency of European countries - was the first step in creating an integrated market covering the whole continent. Moreover, the consistency of law systems and freedom of operations is considered as the main factor which decides about the openness of the market. Additionally, an attractive place for jobs requires assuring the unrestricted mobility of the workforce. Unfortunately, the European market's openness is far behind the traditional freedom of market in the USA, where all 50 states, which can be perceived as analogical to 29 European Economic Area countries, are under the single federal jurisdiction, use the same currency and speak the same language.

Achieving business' and citizens' mobility comparable to the USA is a challenge for European countries. To provide such functionality and to protect countries' sovereignty at the same time, governments and administration structures of all countries must closely cooperate. However, the cooperation and fast as well as errorless information exchange would not be possible without applying advanced Information Technology (IT) solutions. Moreover, competing with the USA in the field of becoming the most competitive knowledge based economy of the world is possible only when the integration level of IT infrastructures of all member states will be sufficiently high $[1,2]$.

Usefulness of IT in supporting administrative tasks is closely bonded with citizens' ability to deal with e-solutions. In the last years citizens e-literacy is growing up around the world. Applying electronic solutions requires citizens to put more trust in their governments, on the other hand IT solutions give more control over the government's actions to citizens. The efficiency of the eGovernment can be improved by raising the overall level of education and computer literacy as well as with the development of the appropriate infrastructure [3].

\section{Decentralisation of the government}

Decentralising government competences arises from the European Treaty and is aligned with the European Union's strategy. A country's law shall guarantee local governments all means necessary to perform their duties. The preamble of the European Charter of Local Self-Governments [4] states: "Considering that the local authorities are one of the main foundations of any democratic regime; Considering that the right of citizens to participate in the conduct of public affairs is one of the democratic principles that are shared by all member States of the Council of Europe; Considering that it is at the local level that this right 
can be most directly exercised;" . The document was ratified by 43 countries at the end of the year $2007^{2}$.

Reorganisation of a country's administrative structure from the central managed structure into the self-governed one was done in Poland in the beginning of democratic reforms. The reorganisation is considered successful and it improved Poland's management especially in the area of European financial aid, which became noticeable shortly before and after accession of Poland to the EU. Local governments improved the success ratio in accepting EU Structural and Consistency Funds.

In the EU the companies are not the only ones who compete between each other. Public agencies, governments, regions, cities compete as well. On the other hand, when a country enters the EU structures, it is bonded by a new set of regulations. Government institutions at the same time compete and cooperate with those in the entire Europe [5].

Moreover, the increased competition between regions is accompanied by the increased mobility of citizens and businesses. Mobile workers are willing to travel to any place to get their dream job. The mobility is embraced by the European Union as a factor which improves the joint European economy's competitiveness. Therefore new services required by citizens and existing services should respond to the increased mobility of citizens. The main issue of citizens' migrations is lack of consistent information exchange architecture/ infrastructure. Institutions use their own systems, which are often incompatible within one country not to mention automated cross-border information exchange. Removing physical borders (on 21.12.2007 the Schengen zone grew to 22 countries) is not accompanied by removing administrative ones.

Centralisation of administrative tasks is impossible from the technological and organisational points of view. Furthermore, it is against the European philosophy of moving the governance closer to people. Finally, centralisation of some tasks can be considered as an attempt on a country's sovereignty. Hence, other means of providing citizens with consistent European-wide administration shall be developed. European countries which reached some advance in developing the e-Government infrastructure developed sets of best practices and interoperability frameworks for that area. These attempts were noticed by the European community and the European Interoperability Framework [6] was created.

Introducing e-Government initiatives at the local level shifts the power from public managers to citizens and businesses. The approach presented in [7] suggests at first shaping e-government initiatives by public managers employed

\footnotetext{
${ }^{1}$ Source: [4]

${ }^{2} \mathrm{http} / /$ conventions.coe.int/treaty/Commun/QueVoulezVous.asp?NT=122\&CL =ENG
} 
by government agencies and afterwards giving more control to local societies. The customers, in the case of the government - citizens and businesses, shall decide what level of technological advancement is necessary to achieve their goals. The paper warns against projecting citizens' or businesses' expectations directly on the e-Government structure. Their expectations can often have a very complex and indirect influence on desired e-Government functionalities.

\section{Local resources for citizens and businesses}

Each country possesses specific material and not material resources. There are various statistics of countries resources' allocations, however, these statistics do not show the real availability of particular resources in particular places. The central government of a country is too far and too concerned with the big picture to micromanage resources at the local level. Making resources available to companies is the task of specialised government agencies, in the case of Poland these agencies are PAIiIZ ${ }^{3}$ (winning and supporting foreign investments) and PARP $^{4}$ (supporting domestic small and medium enterprises). However, these agencies do not own any resources but they contact local governments to ask them for the availability of the resources. This approach makes the process less flexible and more time consuming. Electronic and automated workflow should be introduced to make providing potential investors with resources more efficient.

Despite the growing understanding of the role of the internet in the communication with businesses, using e-Government technologies as a competitive factor of regions is yet to be discovered. Local governments are closer to local societies and can listen to their needs. They also have access to more accurate information about the environment and available resources. The local government knows the detailed structure of the demographic profile of the society, therefore it can conclude what type of companies could benefit most for the region. For example, when the society is young and educated, the local administration should attract research facilities or high tech companies which can utilise locally available workforce.

The main driver of all businesses is to maximise the profit. Outsourcing of various processes gained significant attention in the last years. Companies are moving their production to countries where costs of manufacturing or providing services is lower. However, it is not rare that a cost-effective operation meets obstacles in the form of a huge amount of administrative paperwork to fulfil. Doing accounting for an investment in a foreign country often requires hiring a consulting company or funding a shell company in a target country. The

\footnotetext{
${ }^{3}$ http://www.paiz.gov.pl/

${ }^{4} \mathrm{http}: / /$ www.parp.gov.pl/
} 
additional effort is required because operations in every country are subjected to different jurisdictions and are considered as separate ventures. The additional paperwork creates additional costs.

The availability of government services in Internet evolves and can be divided into phases starting with (1) an initial presence of an institution marked by a simple website with basic information. In further stages the government heads to (2) extending the presence by adding dynamic information, (3) adding interactivity (downloadable forms, gathering feedback) and finally to (4) the transactional level when citizens can use remote connection to initiate transactions, which literally leads to a virtual visit to an institution's branch by interacting with its website. Advancing the interaction level between citizens and the government is accompanied by integrating services from different levels of the government (vertical integration) and by integrating complementary services from different sources (horizontal integration). The final and the most evolved level of the government is the full integration of all services at the country's level. In such a scenario a citizen can access all services from a single website (one-stop-shop), where he or she uses a unique identification name and password (single-log-on) to perform all operations regardless of their origin and to have all fees put on a single consolidated bill. The information exchange between all institutions is integrated both at the presentation layer (from the citizen's point of view) and at the business logic layer (from the institution's point of view) [7].

The issue which makes vertical integration more difficult is the slower progress of the development of electronic services by authorities at the local level. Even in countries with highly developed services at the country's level, the local level is strongly underdeveloped. The situation is better in bigger cities which discovered the potential of electronic access channels earlier than smaller communities. Furthermore, services for businesses tend to be developed in the first place as the more friendly business environment gets more investments in the region. Creating e-Government services at any level is a good start for the propagation of the idea to other levels. Once citizens get acquainted with a service in one institution, they will demand it from other agencies. The same rule applies to agencies, when a decision maker sees how other agency benefits from a particular service, he embraces creating the same service for his institution [7].

\section{Applying software agents}

\subsection{The idea of an agent localising administration units}

The software agents paradigm describes the approach to mobile computing, where mobile code is executed on various host systems. The four main characteristics of a software agent can be distinguished [8]: 
- Intelligence - ability to adapt to changing working environment,

- Cooperative behaviour - negotiating and sharing knowledge with other agents,

- Autonomy - performing specified tasks without any interaction from the user,

- Mobility - ability to transfer to another host system.

More vague definitions describe agency and software agency as reacting to data received from sensors, acting on user's behalf by software entities or acting independently in a dynamic environment [9].

Software agents are being applied to various operations which mainly include information gathering and filtering, and decision making. A carefully designed set of such actions creates an e-commerce flow, including: product brokering, merchant brokering, price negotiations and arranging additional services. The most common application of software agents is supporting Business-toCustomer (B2C) relations by providing customers with "shop bots" and "auction bots" (more in [10]). Although these solutions can be applied for Business-to-Business (B2B) relations as well, dealing with enterprise interaction requires more sophisticated tools. Multi-attribute and multi-subject auctions, contract negotiations and Supply Chain Management (SCM) require dedicated solutions to help companies with achieving the best return from each spent monetary unit. A distinguishable family of negotiating software agents was designed as the answer to businesses needs. The strongest advantage of using software agents, which are able to embed their code into a remote system, is the data mining ability [10].

Software agents can be applied to integrate government services both horizontally and vertically. The agent can localise the appropriate institution according to the given task and perform all the necessary information exchange with it. Moreover, the agent can design and execute automatically the whole chain of operations between multiple organisations to perform a cross-border operation.

An automated, distributed e-Government applications architecture was proposed in [11]. The architecture uses web services, workflow specifications and software agents to automate one of the Finnish government's business processes. A certain level of flexibility is achieved by utilising Business Process Execution Language (BPEL) and the software agents technology. A software agent dynamically creates a workflow process for each service call using available services description. A different approach was suggested in [12], where the Web Digital Government (WebDG) Web Services Management System was introduced. The WebDG utilises a central repository architecture for government services. The system creates a dedicated service for each request 
made by a citizen. The purpose of such an architecture is to achieve the highest Quality of Service (QoS).

Software agents can be applied to customised e-Government services where a set of user profiles is created and an agent associates a profile with a citizen requesting the service. Such an approach can be used to create personalised services for citizens. Such an approach should result in the gain of approval for the administration initiatives. The User Agent associated with a citizen makes an inquiry to the Service Manager Agent for services which may be interesting for the user associated with the User Agent. Services are chosen according to data in profiles stored in the User Profile Database. Profiles consist of demographic data [13].

\subsection{The Infocitizen project}

The unlimited mobility of people and businesses is one of the foundations of the EU. The Infocitizen project addresses that mobility in the area of peoples migrations. The purpose of the Inforcitizen is to use software agents to perform all registration duties required during citizens' migrations. The goal of the project is to allow citizens to contact only the office in the destination country, so he or she is not required to carry on any additional documents from his or her home country. The only document which is sufficient for all purposes is the identification card [14].

The described idea suits the EU policy of removing all barriers for the unrestricted mobility. With the Infocitizen project, all citizens can access any service concerning their registration duties from any place. The project consisted of designing a software agent architecture for local administrative units providing citizens' registration services [14].

The unrestricted mobility is defined as an ability to perform all activities in any place within the EU, just as it would be done in the home country. All documentations related to citizens' birth, changing marital status, birth of a child, adopting a child, registering a new residence, taking a job could be filled in any appropriate office participating in the information exchange (presumably any public service office in the EU).

The scope of the project covers providing services by public administration, requesting services by citizens and interaction between a citizen and public administration units. The whole process is coordinated by the Infocitizen agent. The process of citizens migration involves communicating with the citizen's regional office to update his status. More complicated tasks are for example: marriage and adopting a child. In the case of marriage, offices of both spouses shall be queried about the marital status and the status shall be updated with the new information [14]. 
The Infocitizen's technical architecture is based on the JAVA environment. The architecture is based on utilising a set of services. The services are combined at run-time when a business action is triggered [15].

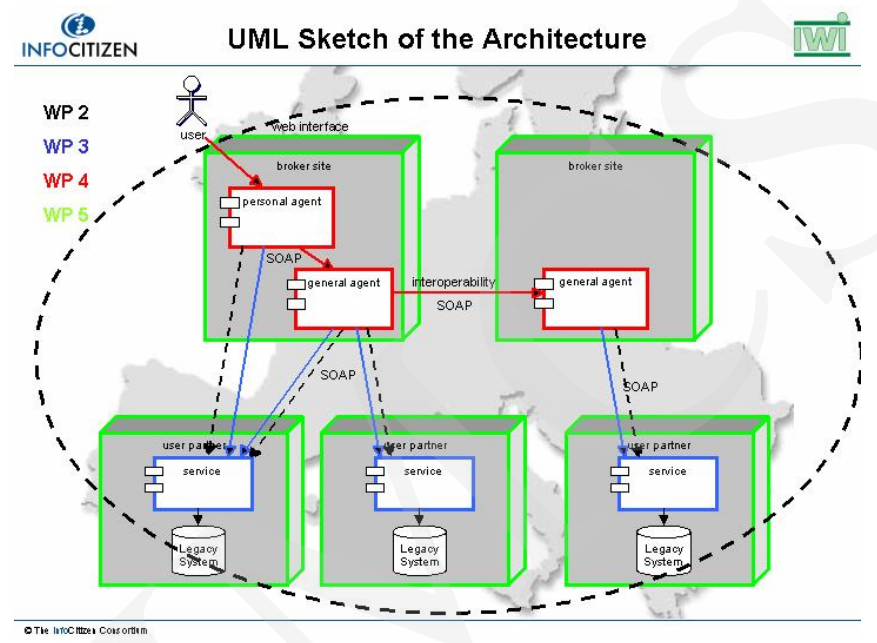

Fig. 1. Logical structure of the Infocitizen architecture [15]

The technical architecture of the Infocitizen is organised in the following way: each public administration unit has its own InfoCitizen Service Interface running on its own IT infrastructure, the InfoCitizen Interoperability Agent is the central component of the InfoCitizen Platform. Agents are utilized on "asneeded" basis. Several agents can exist within the architecture. The structure of software components of the Infocitizen architecture is shown in Fig. 1. An administrative unit requests a service from an agent. The agent who responds to the request carries out all tasks, including getting any additional input from the citizen or administrative employee. The other components are: the services repository, the interface between the agent infrastructure and legacy systems in administration offices, and maintenance and development components [16].

\subsection{Aiding interactions between governments and businesses}

Relations between governments (or local governments) and business can be considered twofold [17]:

1) a company is a subject of administrative responsibilities (G2B relation),

2) multiple governments (or local governments) compete to make a company invest on their soil (B2G relation).

Applying a software agent to act as a proxy who contacts all regions to gather necessary information for a company would benefit both the company and the whole business environment. Companies can make their decision based on 
accurate and exhaustive data and local societies can compete between each other by making their regions more attractive for businesses. Local governments can even create coalitions with neighbouring societies from different countries to gain an attractive investor for the region. The "Euroregion" initiative is an example of cross-border cooperation of local governments within the EU. With software agents interactions between companies and local governments/societies can be independent of the administrative borders and of information systems frames. An agent can seek necessary resources in a heterogeneous environment.

\section{Conclusions}

Trying to integrate already decentralised administration structure would be a step back in the effort of making citizens' and businesses' flows easier. Applying an agent-ready framework, where citizens and businesses can set up a software agent to make their inquiries or perform their tasks is a compromise between the total centralisation and the autonomy of every country in managing their own systems. The most efficient vision of the government of the future is the vision of a single website where citizens and companies from any country belonging to a community (the European Union in the case of Europe) can do all government-related tasks regardless of their localisation and formal registration. The website should be accompanied by a single toll-free number where callcentre consultants can assist the user in solving all issues. The rules which apply to customer services in the government are not different from those which apply to businesses, as citizens are used to the customer service provided by businesses.

Considering government services from the angle of the three-tier software model, the single website (one-stop-shop) should provide integration of all government services at the presentation layer. User input shall be converted to a common data model for an agent which creates a task based on the provided data. Enabling more services in the manner applied in the Infocitizen project allows to achieve the desired interoperability level with preserving the autonomy off all countries in designing their administration. If the EU makes a requirement of extending all services to support the software agents infrastructure, countries can develop e-Government services according to their own visions constrained only by the single condition of the agent enablement.

A software agent can take over the role of an institution whose duty is to support companies when investing in a country. The agent can search for the best source of requested resources regardless of the country, which will enable internal competition and create a strong motivation to improve the business environment. The agent can perform the matchmaking of companies and regions

${ }^{5}$ http://www.pomerania.net/ 
in order to achieve maximal synergetic effect or proper alignment. Maximising properties of individual regions creates a bottom-up effect on the economic growth of the joined European economic space.

\section{References}

[1] Working together for growth and jobs: A new start for the Lisbon Strategy. Commission of the European Communities, Brussels, (2005).

[2] Blanke J., The Lisbon Review 2006: Measuring Europe's Progress in Reform. World Economic Forum, Cologny/Geneva, (2006).

[3] Evans D., Yen D.C., E-Government: Evolving relationship of citizens and government, domestic, and international development. Government Information Quarterly, 23 (2006) 207.

[4] European Charter of Local Self-Government, European Treaty Series - No. 122. Council of Europe, Strasbourg, (1985).

[5] Grosse T.G., Polska w Unii Europejskiej: wyzwanie dla polskiej administracji, Analizy $i$ Opinie. Instytut Spraw Publicznych, Warszawa, (2003), in Polish.

[6] European Interoperability Framework for pan-European e-Government services. IDABC, Luxembourg, (2004).

[7] Gil-Garcia J.R., Martinez-Moyano I.J., Understanding the Evolution of e-Government: The Influence of Systems of Rules on Public Sector Dynamics, Government Information Quarterly, 24 (2007) 266.

[8] Wong J.S.K., Mikler A.R., Intelligent Mobile Agents in Large Distributed Autonomous Cooperative Systems. Journal of Systems and Software, 47 (1999) 75.

[9] Paprzycki M., Software Agents as an Methodology for Creating Software. e-Informatyka.p1 (2003), in Polish.

[10] He M., Leung H.-f., Agents in E-Commerce: State of the Art. Knowledge and Information Systems, 4 (2002) 257.

[11] Korhonen J., Pajunen L., Puustjärvi J., Requirements for Using Agent-Based Automation in Distributed e-Government Applications, Electronic Government, (2003) 157.

[12] Bouguettaya A., Medjahed B., Rezgui A., Ouzzani M., Liu X., Yu Q., WebDG - A Platform for E-Government Web Services, Conceptual Modeling for Advanced Application Domains. (2004) 553.

[13] De Meo P., Quattrone Q., Ursino D., Using Intelligent Agents in e-Government for Supporting Decision Making About Service Proposals. Foundations of Intelligent Systems, (2006) 147.

[14] Vassilios Peristeras J.C., State of the Art, Agent based negotiation for inter- and intraenterprise coordination employing a European Information Architecture for Public Administration, (2001).

[15] Peristeras V., Tarabanis C., Iarussi L., Latini L., Conti A., Pegorari T., Gordo J.I., Morera D., Pina E., Fidalgo J., Kosmidis D., Vogiatzi F., Kalogeraki I., Altmeyer D., Angeli R., Hans S., Lambrecht M., Werth D., Requirements Analysis for the User Partners and Integration to pan-European Approach, Agent Based Negotiation for Inter- and Intra-Enterprise Coordination Employing a European Information Architecture for Public Administration (Infocitizen), (2002).

[16] Adam O., Carvalho J.Á., Fragidis G., Hans S., Lambrecht M., Martinez A.F., Moreira H.M., Parousi V., Peristeras V., Serna Ó., Sá-Soares D., Tarabanis K., Werth D., Report on InfoCitizen Enterprise Architecture Prototype, InfoCitizen - Agent Based Negotiation for Inter- and Intra-Enterprise Coordination Employing a European Information Architecture for Public Administration, (2002).

[17] Hübner U., Introduction to eBusiness, eBusiness in Healthcare, (2008) 3. 